\title{
Interactions of overburden failure zones due to multiple-seam mining using longwall caving
}

\author{
Wanghua Sui $\cdot$ Yuan Hang $\cdot$ Luxing Ma $\cdot$ \\ Zhaoyang Wu $\cdot$ Yongjie Zhou $\cdot$ Guoqing Long • \\ Lianbo Wei
}

Received: 5 April 2014/ Accepted: 4 September 2014/Published online: 27 September 2014

(c) The Author(s) 2014. This article is published with open access at Springerlink.com

\begin{abstract}
This paper presents an investigation on the interactions of overburden failure zones induced by the mining of adjacent coal seams using the longwall caving method. Overburden failure is an important factor in safety assessments in the fields of mining engineering geology and safety geology, especially when mining under water bodies. In this study, the influence of the thickness and properties of the interburden between seams on the development and interactions of caving and fractured water flow zones are investigated by using in situ measurements, scale model testing and numerical simulations. The height of the fractured water flow zones in the scale model tests
\end{abstract}

W. Sui $(\varangle) \cdot$ Y. Hang $\cdot$ L. Ma $\cdot$ Z. Wu $\cdot$ Y. Zhou

School of Resources and Geosciences, State Key Laboratory

for Geomechanics and Deep Underground Engineering, China

University of Mining and Technology, 1 University Ave

(Daxuelu), Xuzhou, Jiangsu 221008, China

e-mail: suiwanghua@cumt.edu.cn

Y. Hang

e-mail: xiaohang_cumt@163.com

L. Ma

e-mail: maluxing_cumt@163.com

Z. Wu

e-mail:wu.xiao.zi@163.com

Y. Zhou

e-mail: zhouyongjie_cumt@163.com

G. Long

Pan-China Group Inc., Chongqing Branch, 85 Jinyudadao, Chongqing 401120, China

e-mail: longguoqing1001@163.com

L. Wei

The Cuizhuang Coalmine Co. Ltd, Weishan County,

Shandong 277606, China

e-mail: wlb8269299@163.com and numerical simulations are basically in good agreement with measurements after mining of the upper and lower seams of Seam No. 3 in the Cuizhuang Coalmine. Therefore, the scale tests and numerical simulations in the study are verified. The results show that interaction and superposition between two close distance seams cannot be ignored when the ratio $(h / M)$ of the interburden thickness $(h)$ to the cutting height of the lower seam $(M)$ is less than a defined critical value. A dividing line, Line $\mathrm{D}$, has been proposed to judge whether the interactions exist. When the $(M, h / M)$ points are located above Line $\mathrm{D}$, the caving zone induced by excavation of the lower seam will not propagate to the caving zone induced by the upper seam. Otherwise, for the $(M, h / M)$ points below Line $\mathrm{D}$, the interactions and superposition of the overburden failure must be considered when predicting the heights of the caving and fractured water flow zones.

Keywords Interactions of overburden failure - Longwall caving $\cdot$ Multiple coal seam mining $\cdot$ Caving zone $\cdot$ Water flow fracture zone $\cdot$ Mining under water bodies

\section{Introduction}

Coal deposition is usually in the form of multiple seams with different interburden thicknesses and geologies. Much research on the interactions of strata stress and deformation due to multiple seam mining have been carried out for room-and-pillar and longwall panels since the 1980s (Mark 2007; Mark et al. 2007). Some of the earlier research mainly focused on room-and-pillar mining. It was found that subsidence and pillar load transfer are two of the typical interactions between adjacent coal beds (Chekan et al. 1986). An evaluation model for the probability of 
multiple seam mining success was proposed by Chanda (1989). Chekan et al. (1988) found that the ratio of the overburden to interburden thickness is a key factor influencing load transfer. Later, multiple seam interactions associated with longwall mining or interactions between room-and-pillar and longwall panels were investigated with a focus on their complex multiple-seam stress and displacement interactions (Chekan et al. 1989; Heasley and Akinkugbe 2005; Porathur et al. 2013). Results demonstrated that during multiple-seam excavations, it is important to protect the overlying workable seams and minimize surface subsidence.

The longwall top coal caving (LTCC) method is an effective mining approach that originated in Europe, and has been widely and successfully used in China. Overburden stress distribution, top coal caving and fracturing mechanisms and evaluations, and interaction between strata movement and hydraulic supports have attracted much attention and have been thoroughly studied since the LTCC method increased in popularity (Xie et al. 1999; Yasitli and Unver 2005; Humphries and Poulsen 2008; Alehossein and Poulsen 2010; Vakili and Hebblewhite 2010; Khanal et al. 2011; Swift 2013; Gao et al. 2014). In recent years, research on the influence of the LTCC method on close-distance seam mining has been carried out by investigating overburden failure and stress distributions using in situ measurements, numerical simulations and scale model testing (Yang et al. 2008; Luan et al. 2010; Zhang and Zhang 2010; Guo 2011; Xu et al. 2013). Results show that interactions on overburden failure during the excavation of close-distance seams are enhanced by the superposition between the floor damage zone of the upper seam and the roof caving zone of the lower seam. This superposition results in increases in the height of the caving and fractured water flow zones of the lower seam, which are greater than those induced by single-seam mining under similar conditions.

Previous studies in the literature revealed some characteristics of the interactions of overburden failure and subsidence induced by the mining of close-distance seams. The damaged interburden and/or caving rocks of the upper seam due to longwall mining constitutes part of the roof of the lower seam. It has been found that the influence of upper seam mining on the stress, deformation and failure of lower seam mining is reduced with increasing interburden thickness. However, the understanding on overburden failure due to multiple seam mining falls short of that on single seam mining, especially in terms of the LTCC method. Some issues require more profound studies and understanding, such as how multiple seams interact during caving mining, to the extent that the thickness and properties of the interburden influence interactions, and how mining sequences and directions of recovery influence interactions. To this end, the main purpose of this study is to investigate the influence of the thickness and geological engineering properties of the interburden between two close seams on the interactions of overburden caving and fracturing, based on a case study of Seam No. 3 (including the upper and lower seams) of the Permian Shanxi Formation in the Cuizhuang Coalmine, Shandong, China.

\section{Hydrogeological and geological engineering conditions}

\section{The Cuizhang Coalmine}

The Cuizhuang Coalmine is located in the Weishan county, $260 \mathrm{~km}$ south of the capital of the Shandong province, Jinan, in China (Fig. 1). Annual mine production was 0.6 million tons from 1998 to 2002 and its annual output has doubled since 2003. The upper and lower seams of No. 3 are the productive coal seams in the Permian Shanxi Formation. The mine was developed by using two vertical shafts and a single mining level at an elevation (EL.) of $-250 \mathrm{~m}$ below the mean sea level (msl). The Cuizhuang Coalmine has an area of approximately $11.9 \mathrm{~km}^{2}$, with a length of $4.2 \mathrm{~km}$ in the east-west direction and a width of $2.5-3.3 \mathrm{~km}$ in the north-south direction. About two-thirds of the total geological coal reserves were deposited under

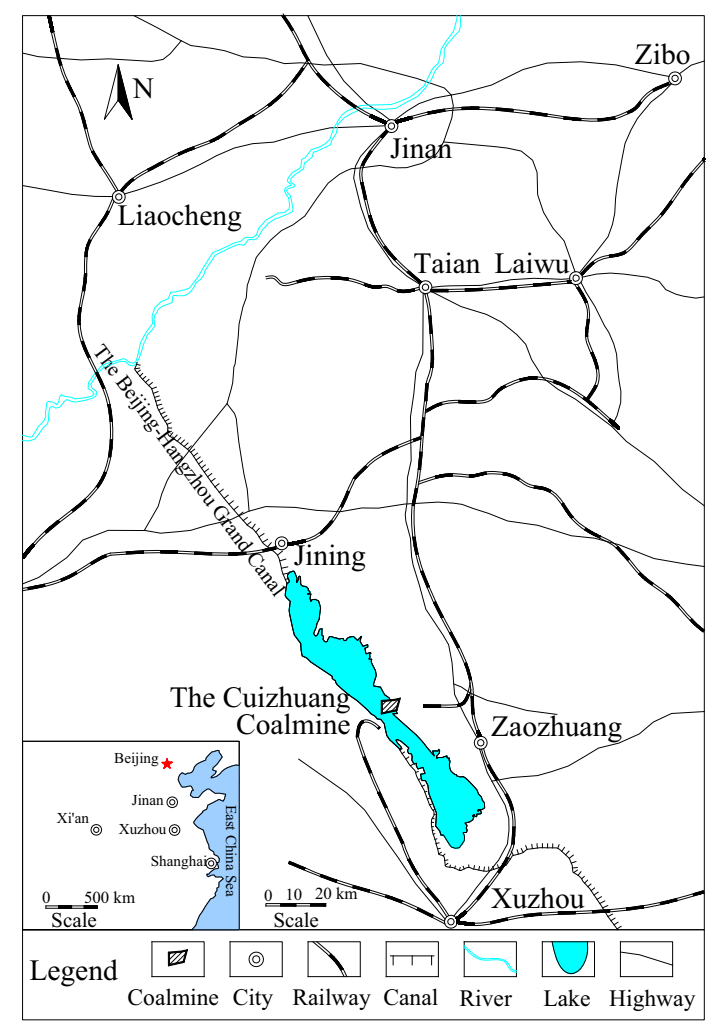

Fig. 1 Location of the Cuizhuang Coalmine 
Weishan Lake, the largest freshwater lake in northern China with an area of $1,266 \mathrm{~km}^{2}$, an average water depth between 1.5 and $3 \mathrm{~m}$, a maximum reservoir of 4.73 billion $\mathrm{m}^{3}$ and a mean water level of EL +32.23 to $+34.21 \mathrm{~m}$.

\section{Lithology and hydrogeology}

Table 1 lists the stratigraphic and hydrogeological characteristics of the Cuizhuang Coalmine. The coal-bearing strata in the mine, the Carboniferous and Permian Systems, are typical coal-measures in the North China coal basin. The Permian Shanxi Formation bears 2-3 coal seams, including the upper and the lower seams of No. 3. The upper seam has a thickness of $0-6.57 \mathrm{~m}$ and the lower seam has a thickness of $0-5.17 \mathrm{~m}$, where zero means sedimentary absence in some of the locations. The Shanxi Formation mainly consists of fine sandstone, mudstone, silty mudstone, siltstone.

The total water inflow in the Cuizhuang Coalmine has been stable with a maximum value of $40 \mathrm{~m}^{3} / \mathrm{h}$, mainly from sandstone aquifers on the roof. The hydraulic relationships between the rock and soil aquifers are separated by several aquifuge layers. However, when coal mining takes place under the Neogene aquifers, the height of the fractured water flow zone is carefully controlled to avoid water and/or sand inrush from unconsolidated aquifers. Therefore, an accurate prediction for the height of overburden failure has become one of the critical issues for risk assessment and mining safety, especially in multiple seam mining.

\section{Tectonic structure}

The Cuizhuang Coalmine is geologically located on the southern rim of the Tengxian anticline hydrogeological setting, which tectonically belongs to the eastern margin of the Western Shandong Block of the North China Platform.

The geological structure of the mine is generally a monocline structure with a set of secondary gently undulating folds, varying in occurrence along the strike and dip directions (Fig. 2). The Cuizhuang anticline and the Chaili synclines are the main structures, accompanied by several normal faults. There are six large faults in the mine, which are boundary faults except for the Tiangang fault and SF1 fault across the mine. Among them, two are hydraulically permeable, two are impermeable, according to groundwater tests, and the remaining two have not been identified. The throw of the Tiangang fault is between 80 and $180 \mathrm{~m}$, extending to the southwest beneath Weishan Lake. It is covered by the Neogene System with a bottom clay

Table 1 Stratigraphy and hydrogeology of the Cuizhuang Coalmine

\begin{tabular}{|c|c|c|c|}
\hline System & Formation & Thickness (m) & Hydrogeology \\
\hline \multirow[t]{2}{*}{ Neogene (N) } & & $57.16-112.42$ & $\begin{array}{l}\text { Three aquifers with an average thickness of } 43.97,37.20 \text { and } 7.82 \mathrm{~m} \text {, specific capacity } \\
q=0.0003,0.6 \text {, and } 0.003 \mathrm{~L} / \mathrm{s} / \mathrm{m} \text {, and coefficient of permeability } K=0.05,4.8 \text { and } \\
0.03 \mathrm{~m} / \mathrm{d} \text {, respectively, influence coal mining adjacent to the weathered zone }\end{array}$ \\
\hline & & & $\begin{array}{l}\text { Aquifuge layers between the first and second aquifers, } 12.00-20.30 \mathrm{~m}(14.39 \mathrm{~m} \text { on } \\
\text { average) thick; aquifuge layers between the second and the third aquifers, } \\
5.40-10.05 \mathrm{~m} \text { ( } 7.92 \mathrm{~m} \text { on average) thick; bottom aquifuge between the third aquifer } \\
\text { and the weathered zone, } 5.31-23.18 \mathrm{~m} \text { in thickness }\end{array}$ \\
\hline Jurassic (J) & & $0-216.50$ & $\begin{array}{l}\text { The Jurassic System is distributed in the northern and eastern part of the mine with } \\
\text { different thicknesses, does not exist in the study panels of this paper. The Jurassic } \\
\text { includes some aquifers and aquifuges. The aquifers are fissured sandstone and } \\
\text { conglomerate aquifers, with a thickness of } 0-60 \mathrm{~m}, q=0.4 \mathrm{~L} / \mathrm{s} / \mathrm{m} \text {, which have little } \\
\text { influence on coal mining at a distance of more than } 140 \mathrm{~m} \text { from Seam No. 3. The } \\
\text { aquifuges are red mudstone and muddy sandstone }\end{array}$ \\
\hline \multirow[t]{2}{*}{ Permian $(\mathrm{P})$} & $\begin{array}{l}\text { Xiashihezi } \\
\text { Formation }\end{array}$ & $\begin{array}{l}212.90 \text { (the } \\
\text { maximum) }\end{array}$ & $\begin{array}{l}\text { Aquifuge layers of mudstone and siltstone that separate the Jurassic aquifers and coal- } \\
\text { measures }\end{array}$ \\
\hline & $\begin{array}{l}\text { Shanxi } \\
\text { Formation }\end{array}$ & $\begin{array}{l}89.60-142.75 \text {, } \\
112.97 \text { on average }\end{array}$ & $\begin{array}{l}\text { Immediate sandstone roof of Seam No. } 3 \text { with a thickness of } 15.05-58.23 \mathrm{~m} \text {; includes } \\
\text { the roof of the upper and lower seams of No. } 3, q=0-0.7 \mathrm{~L} / \mathrm{s} / \mathrm{m} \text {, easily dewatered } \\
\text { during mining }\end{array}$ \\
\hline \multirow[t]{2}{*}{$\begin{array}{l}\text { Carboniferous } \\
\text { (C) }\end{array}$} & $\begin{array}{l}\text { Taiyuan } \\
\text { Formation }\end{array}$ & $\begin{array}{l}150.68-189.95 \\
165.30 \text { on average }\end{array}$ & $\begin{array}{l}\text { Confined karstic and fissured limestone aquifers, including Limestone No. } 3 \text { with a } \\
\text { thickness of } 7.10-9.80 \mathrm{~m} \text { and Limestone No. } 10 \text { with a thickness of } 3.43-7.38 \\
q=0.01-1.6 \text { and } 0.0009 \mathrm{~L} / \mathrm{s} / \mathrm{m} \text {, respectively }\end{array}$ \\
\hline & $\begin{array}{l}\text { Benxi } \\
\text { Formation }\end{array}$ & 40.00 on average & $\begin{array}{l}\text { Includes limestone, inter-bedded siltstone and mudstone, ferrous mudstone, poor water- } \\
\text { yielding capacity }\end{array}$ \\
\hline $\begin{array}{l}\text { Ordovician } \\
\text { (O) }\end{array}$ & & 49.89 (drilled depth) & $\begin{array}{l}\text { Confined karstic and thick fissured limestone aquifer, } q=0.14 \mathrm{~L} / \mathrm{s} / \mathrm{m} \text {, excellent water- } \\
\text { yielding capacity. Groundwater level declines about } 3 \mathrm{~m} \text { annually due to regional } \\
\text { mine drainage }\end{array}$ \\
\hline
\end{tabular}




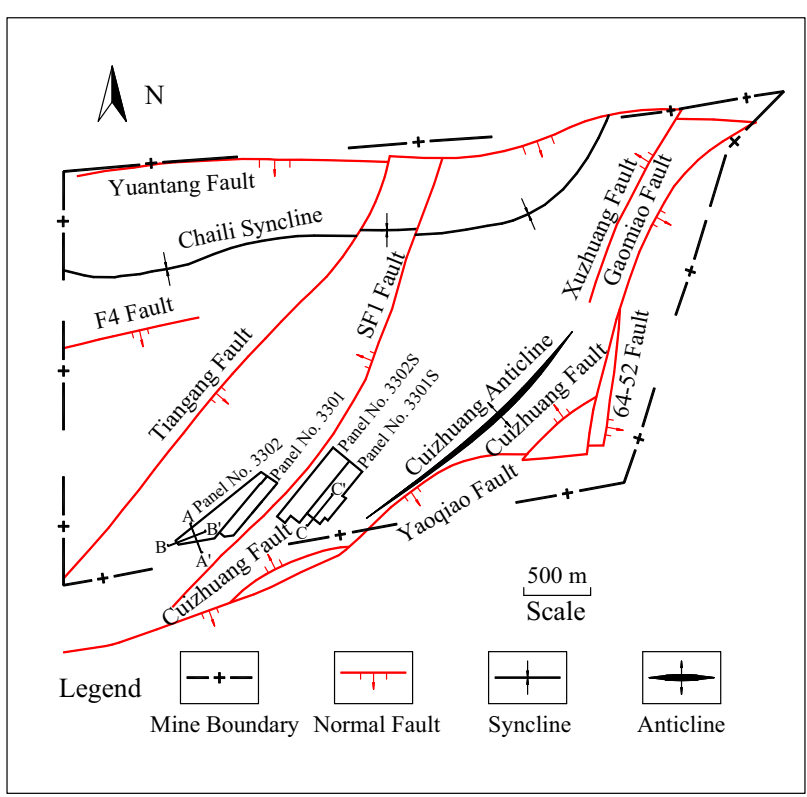

Fig. 2 Tectonic structure with studied panels in the Cuizhuang Coalmine

5.31-23.18 m thick. The bottom clay layer protects the coal mine from water seepage from sand aquifers along the faults in the coalmine.

Engineering geology of overburden and interburden

Figure 2 also shows the four main study panels of this paper. In-situ measurements of overburden failure were conducted in Panel 3301S and Panel 3302S and results were used to verify the scale models and numerical models. The scale model test prototypes are from geological crosssections in Panel 3302 and are shown in Fig. 3. These four panels have similar geological and mining conditions. Figure 3 is an illustration of the cross-sections (section lines $\mathrm{A}-\mathrm{A}^{\prime}, \mathrm{B}-\mathrm{B}^{\prime}$ and $\mathrm{C}-\mathrm{C}^{\prime}$ are shown in Fig. 2) examined for overburden failure and Table 2 lists the geotechnical properties of typical geological engineering types in the Permian Shanxi Formation. Mudstones in the geological column occupy about one-third of the overburden of the No. 3 upper seam. Mudstones, sandy mudstones or siltstone on the roof can be easily damaged, resulting in roof caveins that fill the mined-out area. The overburden strength varies from soft to medium; nevertheless, the strength of the rocks adjacent to the unconsolidated Neogene layers is significantly decreased because of strong weathering. This kind of overburden structure is helpful for resisting the development of fractured water flow zones due to mining. The thickness of the overburden of the No. 3 upper seam varies from $36.4 \mathrm{~m}$ to more than $200 \mathrm{~m}$. The bedrock surface underlying the Neogene sediments is between
-100 and $-70 \mathrm{~m}$ msl with some topographical fluctuations in the coal mining area.

\section{Methodologies}

Overburden failure includes three zones from the roof to surface: caving zone; fractured zone; and bending zone. The permeability in the caving and fractured zones changed dramatically and formed the groundwater pathway from overburden aquifers into the panels. Therefore, the composition of the caving zone and the fractured zone is known as a "water flow fracture zone." The height of the water flow fracture zone is the height from the roof of the seam to the upper boundary of the fractured zone. The caving zone consists of the lower part of the fractured water flow zone (Fig. 4).

\section{Measurements}

In-situ measurements have been one of the most important and direct methods for the investigation of the height of overburden failure zones. In this traditional measurement method, water loss is investigated by the drilling of boreholes. Currently, underground water pumping, ultrasonic imaging and other geophysical approaches have been adopted in overburden failure measurement. Figure 4 shows the principles of ground and underground measurement methods using boreholes.

A so-called two-terminal plugging tool was used in the Cuizhuang Coalmine to measure water loss in different boreholes to determine the height of the overburden failure zone. The boreholes were designed and drilled before and after mining. The borehole was separated into $0.1 \mathrm{~m}$ or 0.2 $\mathrm{m}$ sections. The ends of each section were plugged with an expansion rubber inside the borehole. High pressure water was injected into the isolated section and water loss was measured prior to and after coal mining. The height of the fractured water flow zone was determined by comparing water loss along the boreholes pre- and post-excavation (Xu and Sui 2013).

Scale model test

Scale model testing is one of the common methods used in the research of overburden failure. In this study, the dimensions of the scale model test rig are $6 \mathrm{~m} \times 3 \mathrm{~m} \times$ $0.4 \mathrm{~m}$ (length $\times$ height $\times$ thickness). The model parameter scales are as follows: (1) 1:200 for geometry; (2) 1:1.7 for gravity; and (3) 1:200 for uniaxial compressive strength (UCS). Materials used for modeling comprised a combination of sand, barite, gypsum, mica, sawdust, etc. Mica powder was well distributed between the rock layers to 
Fig. 3 Geological crosssections

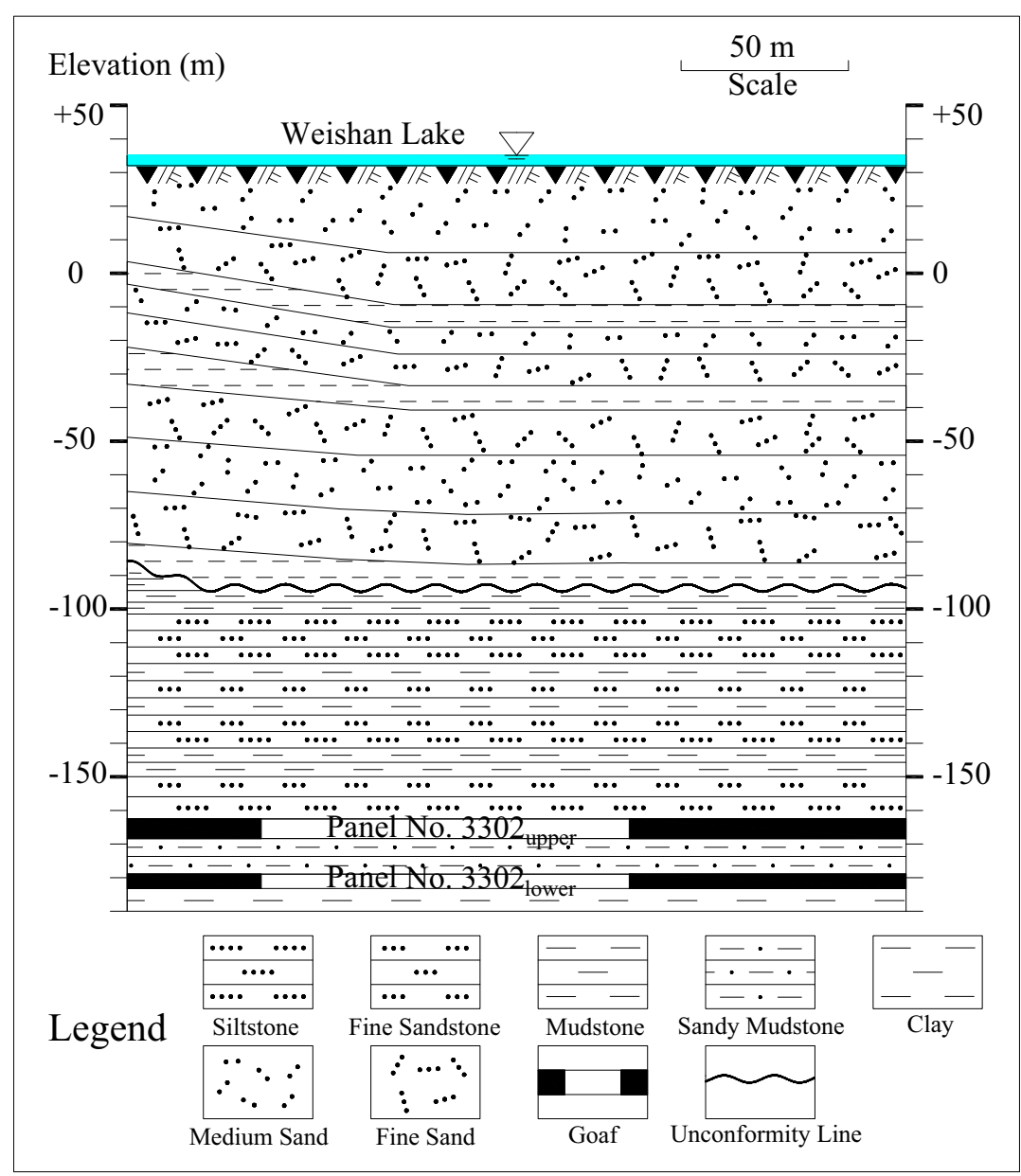

(a) A- A' cross section along the strike in Panel No. 3302 simulate formation beddings. A distributed load was applied to the scale model to compensate for gravitational pressure of the overburden.

Table 3 lists the four types of scale modeling conducted in this paper to simulate different mining and geological conditions. The major differences among them are found in the cutting height and the interburden thickness. Scale Model (SM) No. 1 simulates Panels No. 3301S $\mathrm{S}_{\text {upper }}$ and $3301 \mathrm{~S}_{\text {lower }}$ to verify the scale modeling through a comparison of the height of the overburden failure zone with that from the in situ measurements. SM No. 2 is basically the same as SM No. 1 except that the interburden is changed to $14 \mathrm{~m}$ to study the influence of the interburden thickness on the height of the overburden failure zone. The other two models, SMs No. 3 and 4, are designed to simulate fracture propagation due to mining in the close-distance seams in Panel 3302 along the dip and strike cross sections (illustrated in Fig. 5) that correspond to those in Fig. 3. In SMs No. 3 and 4, the cutting height of the upper and the lower seams is 6.0 and $4.3 \mathrm{~m}$, respectively; the thickness of the interburden is $10.6 \mathrm{~m}$. Excavation was carried out in the mining entrance from left to right. Every day, a 4-cm seam (in model size) of coal was mined out; this equals $8 \mathrm{~m}$ in the prototype. The lower seam was mined by using the same process after excavation of the upper seam was completed. The displacement of the strata during the mining simulation was measured by using linear variable differential transformers (LVDTs). For every step of the excavation, the deformation and failure of the overburden were recorded and images were taken with a high speed camera. Then, the movement and deformation due to mining were analyzed by digital image processing.

\section{Numerical simulation}

Numerical modeling needs to be verified and validated against (1) the overburden failure measurement in the study area and (2) the overburden failure induced by fracture propagation in the scale experiments before it can be used to study multiple seam interactions in mining. It was found that the location of a sudden change of vertical displacement, which shows a concentration of vertical displacement 
Fig. 3 continued

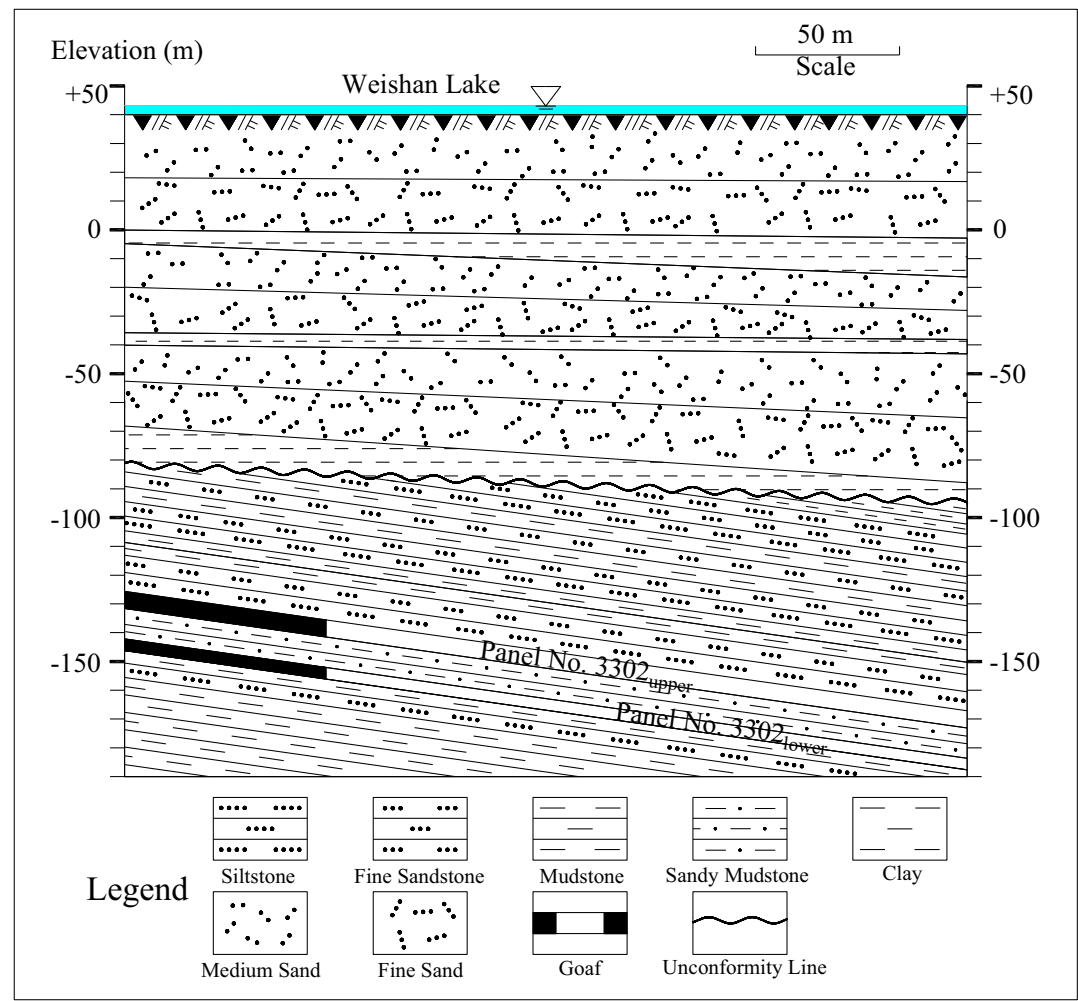

(b) B - B' cross section along the dip in Panel No. 3302

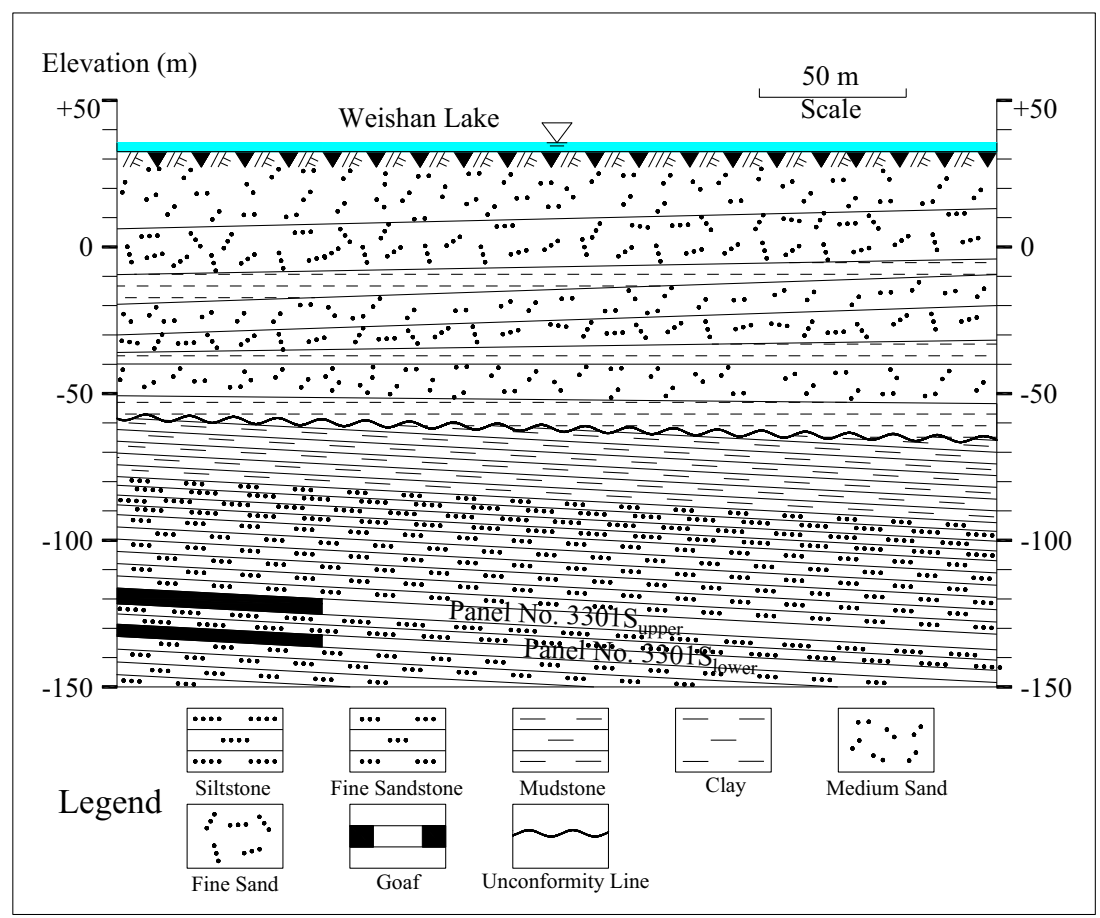

(c) C - C' cross section along the dip in Panel No. 3301S

isolines, is in good agreement with the height of the caving zone; the height of the zone with continuous tensile cracks is in an agreement with the height of the fractured water flow zone. Therefore, the propagation of tensile and shear failures, and the distribution of displacement can be used to evaluate the heights of the caving and fractured water flow zones. 


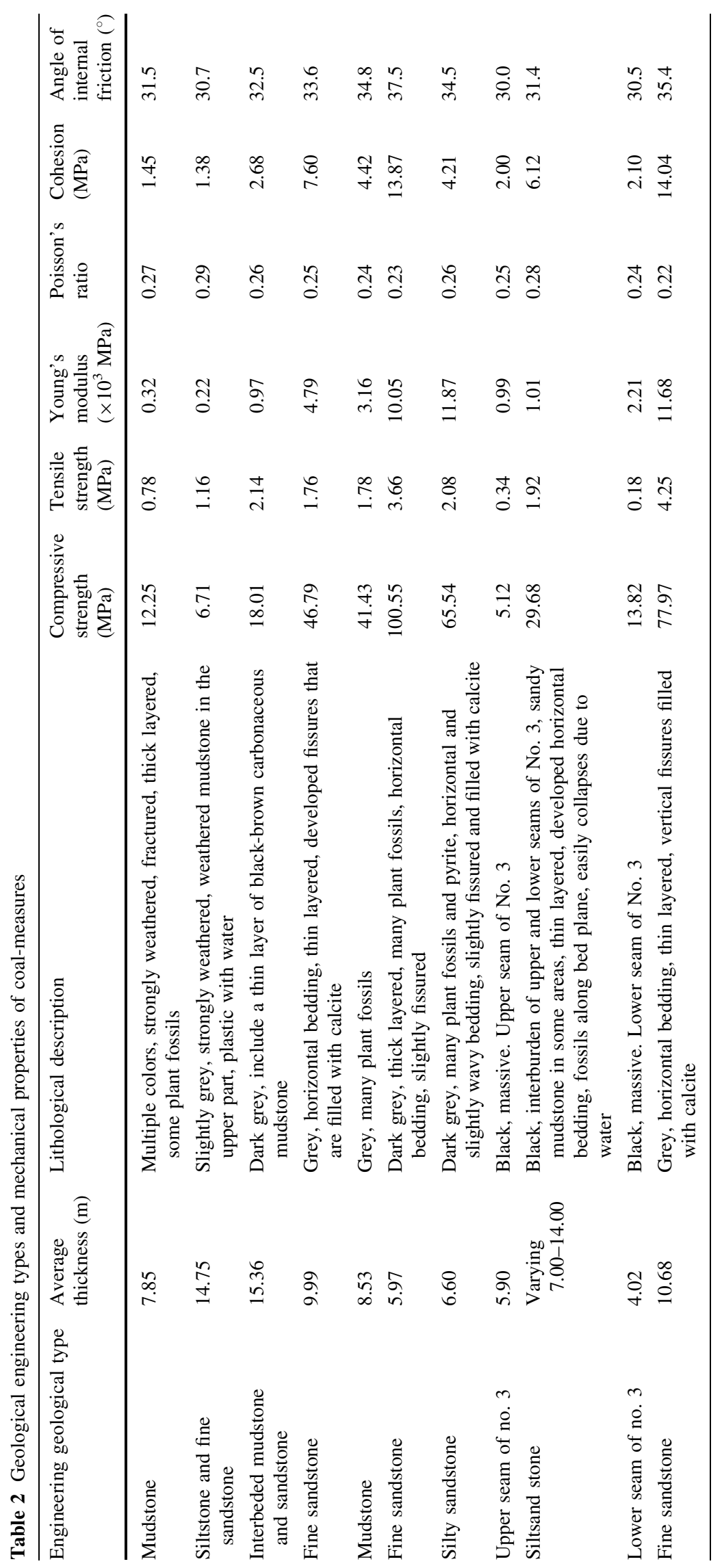


Fig. 4 Principle schematic of in situ measurement for the height of overburden failure. $H_{f}$ height of water flow fractured zone, $H_{c}$ height of caving zone

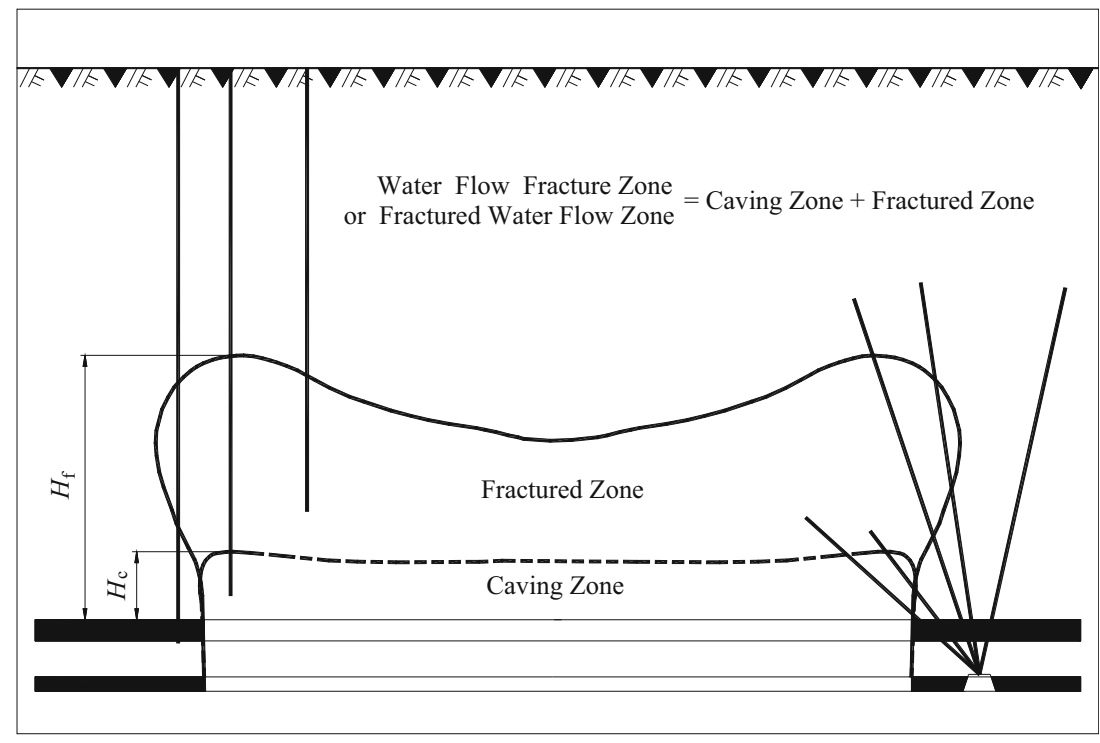

Table 3 Scale modeling

\begin{tabular}{|c|c|c|c|c|c|}
\hline Scale model no. & Purpose & $\begin{array}{l}\text { Prototype } \\
\text { panel no. }\end{array}$ & $\begin{array}{l}\text { Cutting height } \\
\text { of upper seam (m) }\end{array}$ & $\begin{array}{l}\text { Cutting height } \\
\text { of lower seam } M(\mathrm{~m})\end{array}$ & $\begin{array}{l}\text { Thickness of } \\
\text { interburden } h(\mathrm{~m})\end{array}$ \\
\hline SM no. 1 & Verification of scale modeling & $3301 S$ & 5.0 & 4.0 & 7.0 \\
\hline SM no. 2 & Determine influence of interburden thickness & _ & 5.0 & 4.0 & 14.0 \\
\hline SM no. 3 & Determine propagation of fractures & 3302 strike & 6.0 & 4.3 & 10.6 \\
\hline SM no. 4 & Determine propagation of fractures & 3302 dip & 6.0 & 4.3 & 10.6 \\
\hline
\end{tabular}

A Fast Lagrangian Analysis of Continua (FLAC 2D) code (Itasca 2009) was used in this study. Boundary conditions for the plane strain models are free displacement and loading on the top, fixed at the bottom, fixed in the horizontal direction and free in the vertical direction on both side boundaries. Parameters of the different geological engineering types were carefully determined by using laboratory tests and geological observations in accordance with the Hoek-Brown criteria (Hoek and Brown 1997). Extraction of coal was conducted by the function of "model null" in the code. The maximum convergence between the roof and floor was limited to less than the cutting height of the seam.

\section{Results and analysis}

Measurement and verification for modeling

Two panels of the Cuizhuang Coalmine were selected for overburden measurements: Panels No. $3301 \mathrm{~S}_{\text {upper }}$ and $3301 S_{\text {lower }}$ (locations shown in Fig. 2 and Panel No. 3301S denoted). The upper and the lower seams of No. 3 were separated by a $7 \mathrm{~m}$ thick interburden composed of grey, thin-layered silty mudstone and siltstone. Significant amounts of fossilized plant fragments were found along the bedding plane that grew on the horizontal bedding on the interburden, meaning that caving easily took place and filled the mine gob after excavation of the lower seam. The dip angle of the strata above the panels was $8^{\circ}$ on average and varied between $0^{\circ}$ and $11^{\circ}$.

The above-mentioned water loss method was used to measure overburden failure induced by upper seam mining with LTCC and carried out on Panel No. 3301S $\mathrm{S}_{\text {upper }}$ with 3 underground boreholes. The measurements were completed on July 2007. Results showed the maximum height of the caving zone is $19.6 \mathrm{~m}$; the maximum height of the fractured water flow zone is $59.59 \mathrm{~m}$ above the roof of the upper seam. The height ratio of the caving and fractured water flow zones against the cutting height of $5.0 \mathrm{~m}$ is 3.9 and 11.9, respectively. Measurements for the lower seam were conducted on Panel No. $3301 \mathrm{~S}_{\text {lower }}$ just beneath Panel No. $3301 \mathrm{~S}_{\text {upper }}$. Measurements were completed in November 2008 and shortly thereafter mining was stopped on the panel. The maximum height of the fractured water flow zone after mining the $4.0 \mathrm{~m}$ lower seam was $66.0 \mathrm{~m}$ above the roof of the upper seam. An equivalent cutting height thickness of the upper and lower seams can be calculated by using Formula (1) in accordance with a code from the China State Bureau of Coal Industry (2000), which is $7.2 \mathrm{~m}$ and the ratio of the height of the fractured 


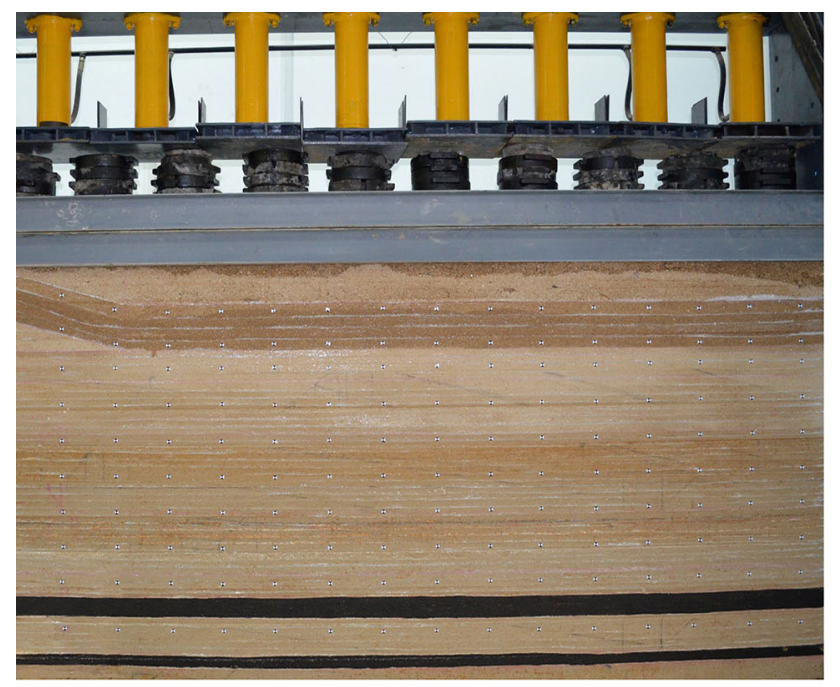

(a) Scale Model No.3 along the strike which corresponds to Fig.3a

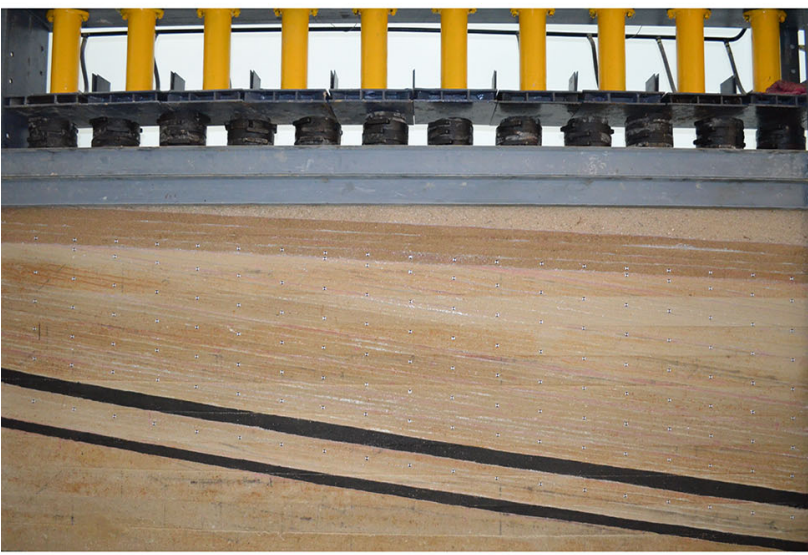

(b) Scale Model No.4 along the dip which corresponds to Fig.3b

Fig. 5 Pictures of two scale models before excavation of a coal seam

water flow zone against the equivalent cutting height of $7.2 \mathrm{~m}$ is 9.2 .

$M=M_{\text {lower }}+\left(M_{\text {upper }}-h_{\text {interbrden }} / y_{\text {lower }}\right)$

where $M$ is the equivalent thickness of the upper and lower seams; $M_{\text {upper }}$ and $M_{\text {lower }}$ are the cutting height of the upper and lower seams, respectively; $h_{\text {interburden }}$ is the thickness of the interburden; $y_{\text {lower }}$ is the ratio of the height of the caving zone to the thickness of the lower seam; this study assumes that it has the same value of 3.9 as the upper seam does.

Therefore, predicting the height of the fractured water flow zone $H_{\mathrm{f}}$ for mining the upper and the lower seams of No. 3 in the Cuizhuang Coalmine can be calculated by using the formula $H_{\mathrm{f}}=9.2 \mathrm{M}$ that takes interactions into account with a rule of thumb. Here, please note that the heights of overburden failure are calculated from the roof of the upper seam.

For verification purposes, Table 4 shows a comparison of the physical and numerical simulations based on in situ measurements, numerical simulations and scale modeling. The results show the interactions lead to the superposition of overburden failure due to the mining of two close distance seams. The height of the fractured water flow zone is increased from 52.1 to $68.0 \mathrm{~m}$ because of superposition failure due to excavation of the upper and lower seams with an interburden thickness of $7 \mathrm{~m}$, see SM No. 1. The results in Table 4 verify the feasibility of using numerical simulation and scale modeling to study overburden failure, caving and fracturing interactions in multiple-seam mining. The results from SM No. 2 show that the height of the fractured water flow zones is increased from 52.1 to $64.8 \mathrm{~m}$ above the roof of the upper seam, thus indicating the influence of the interburden thickness when it is changed to $14 \mathrm{~m}$. These results indicate there is still interaction of rock caving and fracturing in close-seam mining when the interburden thickness reaches $14 \mathrm{~m}$, but the interaction increases when the interburden thickness is $7 \mathrm{~m}$.

\section{Fracture propagation}

Figure 6a-d presents pictures showing the performance of selected stages during and after mining of the upper seam of No. 3 from SM No. 3. The development of caving and fractured water flow zones can be interpreted through a detailed analysis of the mining process in a stepwise consecutive manner. The first caving occurred when panel length was advanced to $24 \mathrm{~m}$ (the prototype size, same below in this paper). After that, the roof periodically cracked and the height of the caving and fractured water flow zones gradually increased until rocks filled the mined out area behind the working face. Rocks almost fully filled the mined

Table 4 Comparison of overburden failure among in situ, scale modeling and numerical measurements

\begin{tabular}{|c|c|c|c|c|c|c|c|}
\hline \multirow[t]{2}{*}{ Seam } & \multirow[t]{2}{*}{ Cutting height $(\mathrm{m})$} & \multicolumn{3}{|c|}{ Height of caving zone $H_{\mathrm{c}}(\mathrm{m})$} & \multicolumn{3}{|c|}{ Height of fractured water flow zone $H_{\mathrm{f}}(\mathrm{m})$} \\
\hline & & Measurement & $\begin{array}{l}\text { Numerical } \\
\text { simulation }\end{array}$ & $\begin{array}{l}\text { Scale model } \\
\text { no. } 1\end{array}$ & Measurement & $\begin{array}{l}\text { Numerical } \\
\text { simulation }\end{array}$ & $\begin{array}{l}\text { Scale model } \\
\text { no. } 1\end{array}$ \\
\hline Upper seam of no. 3 & 5.0 & 19.6 & 15.0 & 16.8 & 59.6 & 55.0 & 52.1 \\
\hline Lower seam of no. 3 & 4.0 & - & 23.0 & 24.5 & 66.0 & 64.0 & 68.0 \\
\hline
\end{tabular}

Heights are measured from the roof of the upper seam 


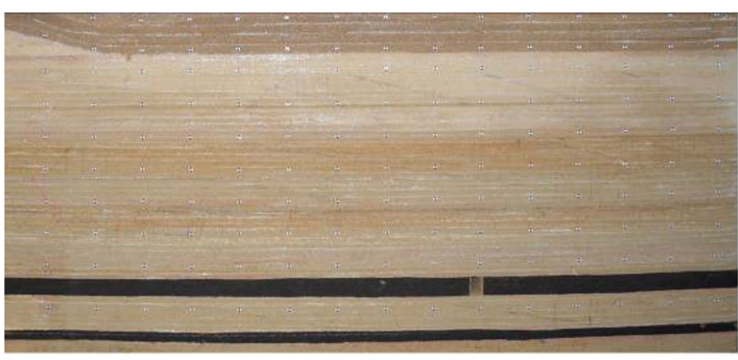

(a) Stage 1 (upper $4 \mathrm{~m}$ )

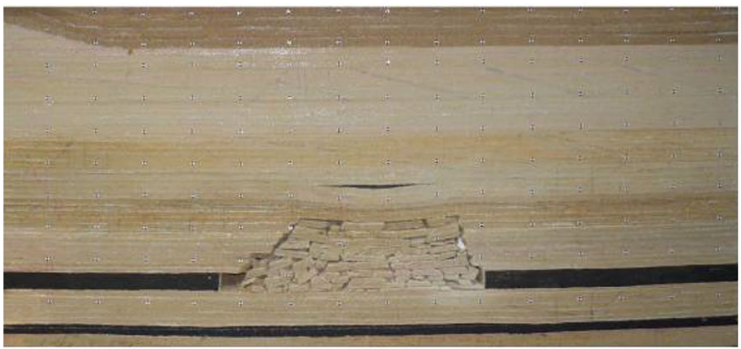

(c) Stage 3 (upper $84 \mathrm{~m}$ )

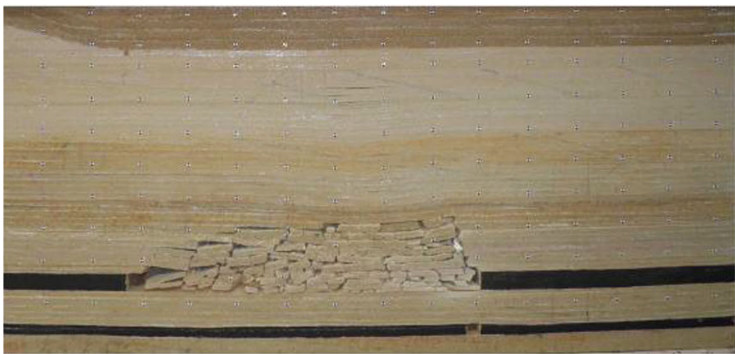

(e) Stage 5 (lower $4 \mathrm{~m}$ )

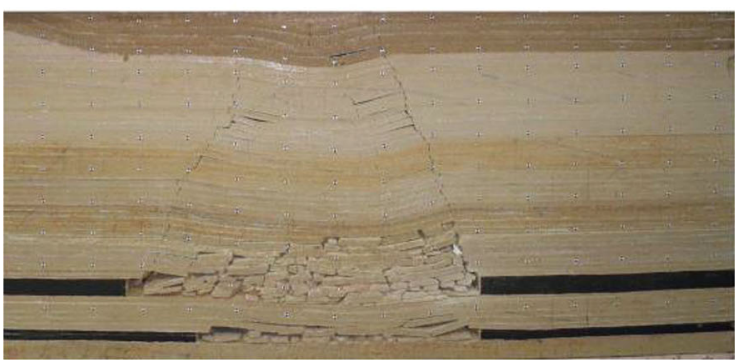

(g) Stage 7 (lower $88 \mathrm{~m}$ )

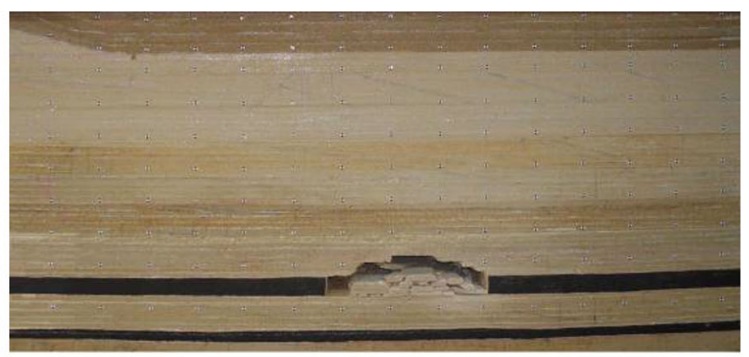

(b) Stage 2 (upper $52 \mathrm{~m}$ )

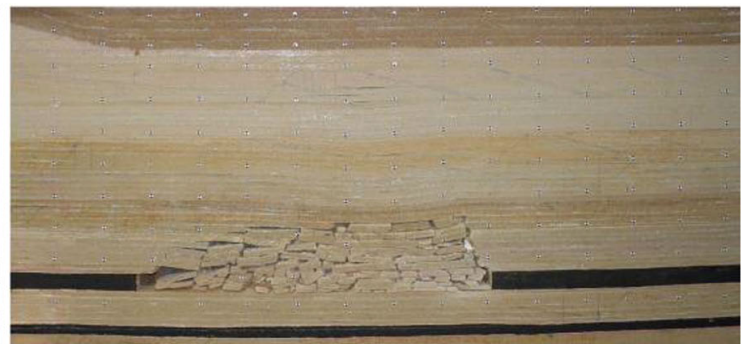

(d) Stage 4 (upper $110 \mathrm{~m}$ )

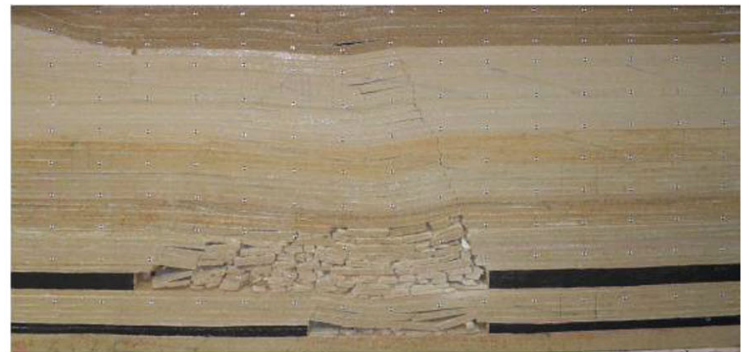

(f) Stage 6 (lower $56 \mathrm{~m}$ )

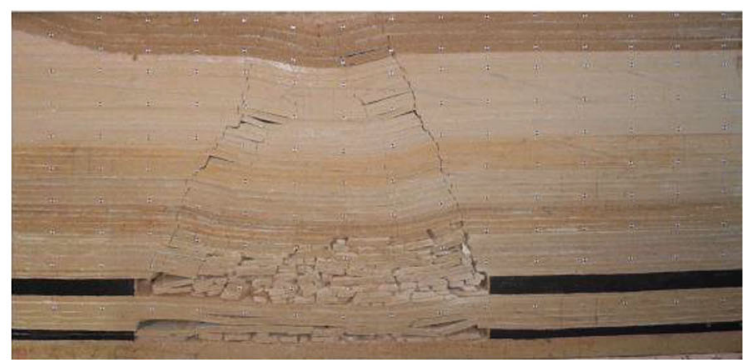

(h) Stage 8 (lower 110 m)

Fig. 6 Pictures of fractures during seam excavation along the strike from SM No. 3

out area when the recovery length reached $84 \mathrm{~m}$. After mining, the height of the caving and fractured water flow zones reached 17.6 and $48.0 \mathrm{~m}$, respectively. The height of the fractured water flow zone was expected to increase if recovery of coal continued. The outline of the fractured water flow zone has the shape of an asymmetric ladder.

Figure $6 \mathrm{e}-\mathrm{h}$ show development of the overburden failure zone during mining of the lower seam of No. 3 from SM No. 3. The interburden between the upper and lower seams did not cave until the distance of coal recovery reached $44 \mathrm{~m}$; the fractured water flow zone also did not develop further until this length. The caving zone of the upper and lower seams merged into one another when the mining length was advanced to $56 \mathrm{~m}$, and the height of the fractured water flow zone continuously increased until its ladder-shaped outline reached the bottom clay layer.

Figure 7 shows caving height variations and fractured water flow zones with coal recovery in the coal seam. Caving zone heights reaches the maximum value first, and then the fractured water flow zone reaches its highest position with a longer recovery distance, depending on the cutting height and overburden features. The maximum 

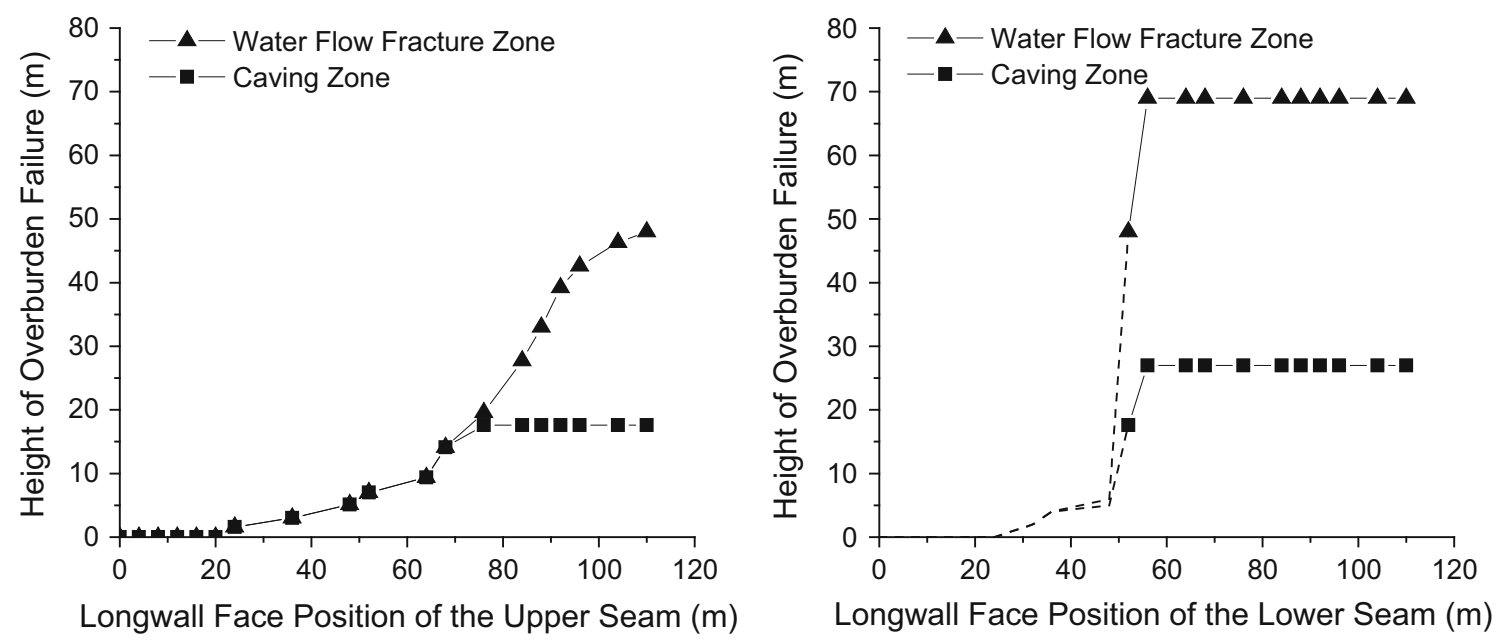

Fig. 7 Height variations of overburden failure with coal recovery from the upper and lower seams along strike from SM No. 3

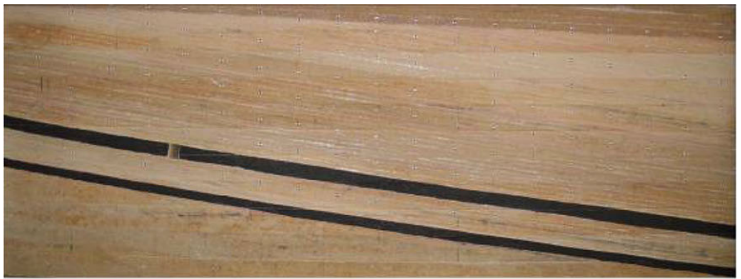

(a) Stage 1 (upper $4 \mathrm{~m}$ )

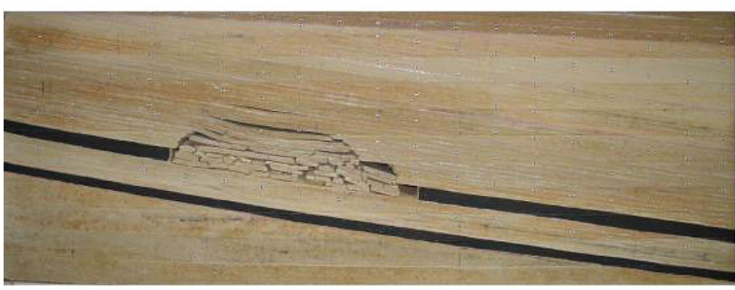

(c) Stage 3 (upper $96 \mathrm{~m}$ )

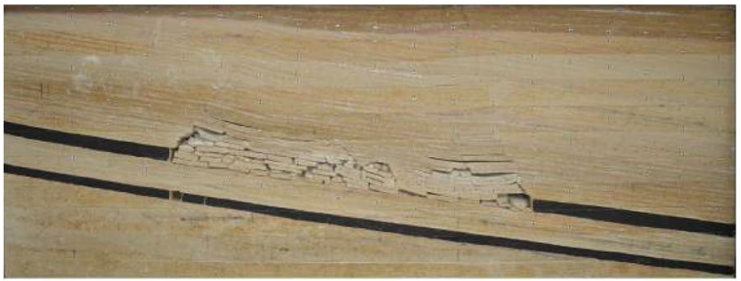

(e) Stage 5 (lower $4 \mathrm{~m})$

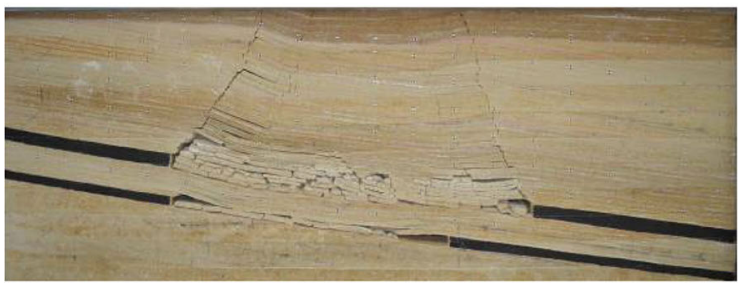

(g) Stage 7 (lower $108 \mathrm{~m}$ )

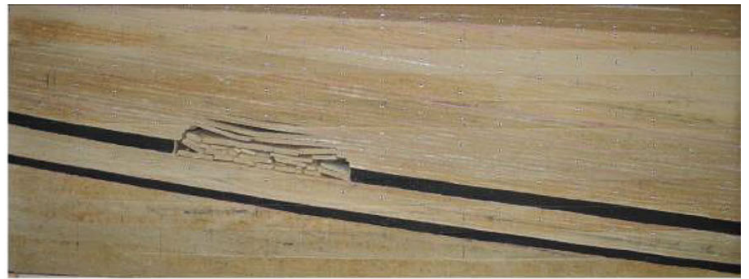

(b) Stage 2 (upper $68 \mathrm{~m}$ )

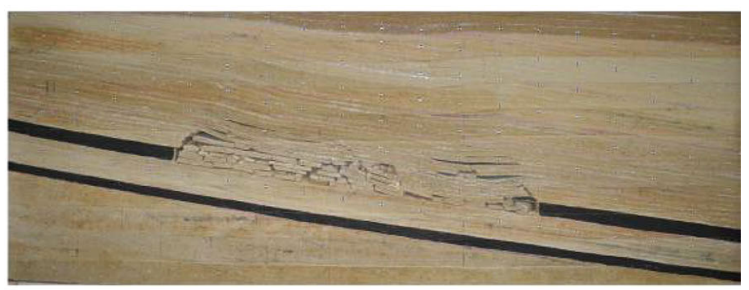

(d) Stage 4 (upper $140 \mathrm{~m}$ )

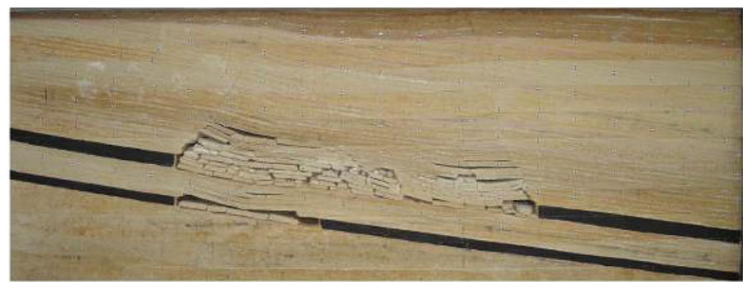

(f) Stage 6 (lower $56 \mathrm{~m}$ )

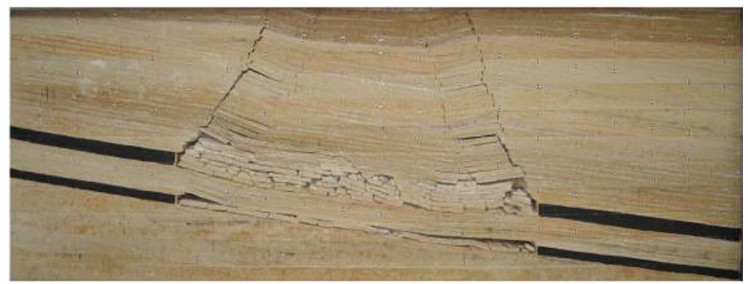

(h) Stage 8 (lower 140 m)

Fig. 8 Pictures of fractures during seam excavation along dip from SM No. 4 

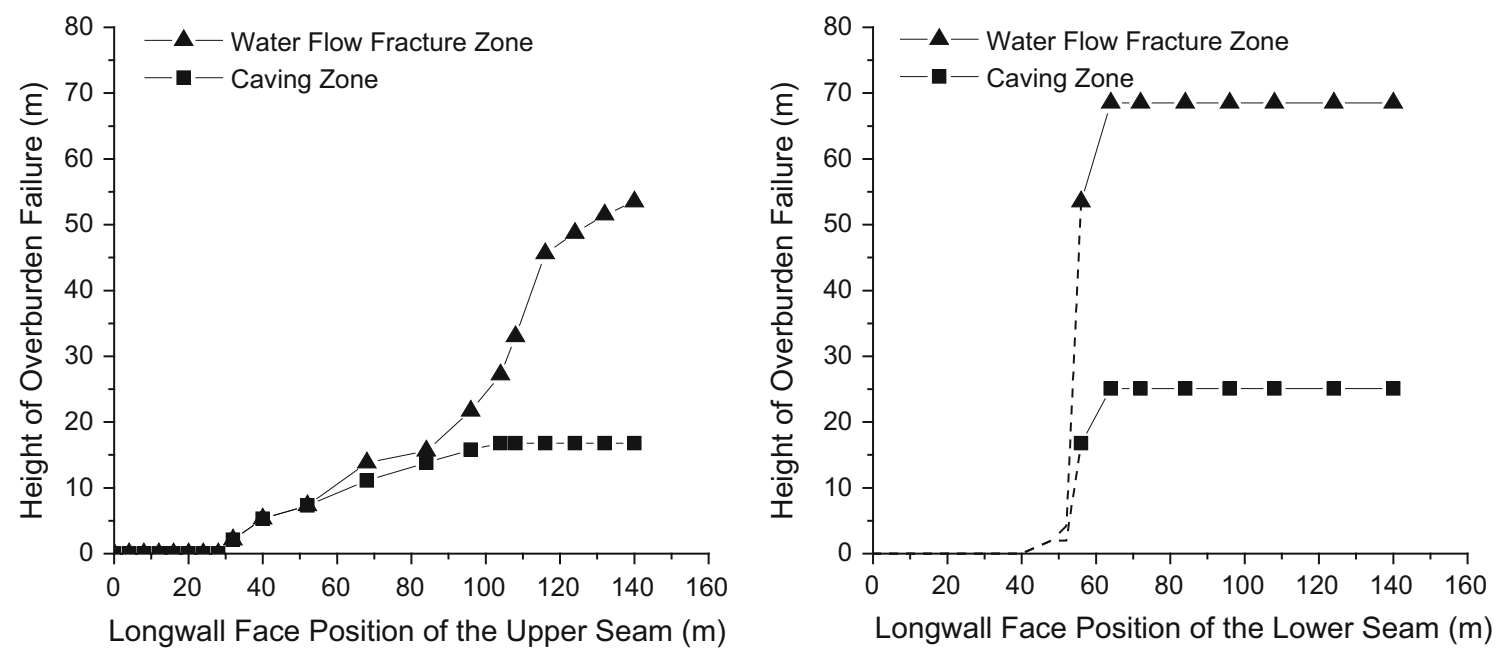

Fig. 9 Height variations of overburden failure with coal recovery in the upper and lower seams along dip from SM No. 4

height of both zones is 27.0 and $69.0 \mathrm{~m}$, respectively, above the upper seam after the excavation of the upper and lower seams of No. 3 along the strike direction.

Figure 8a-d show development of caving and fractured water flow zones due to the recovery of coal from the upper seam along the dip direction from SM No. 4. There is little caving and fracturing until the excavation length reached $28 \mathrm{~m}$. The first caving occurred when the panel length was increased to $32 \mathrm{~m}$ and then the roof periodically cracked. Furthermore, the height of both zones gradually increased. When rocks completely filled the mined out area, the propagation of the caving zone stopped, while the height of the fractured water flow zone continued to slowly increase until a length of about $120 \mathrm{~m}$. After mining, the heights of the caving zone and fractured water flow zone were 16.8 and $53.5 \mathrm{~m}$, respectively.

Figures $8 \mathrm{e}-\mathrm{h}$ and 9 show the overburden failure zone during mining of the lower seam of No. 3 from SM No. 4 after excavation of the upper seam. The interburden between the upper and lower seams did not cave until coal recovery reached a distance of $44 \mathrm{~m}$ and the fractured water flow zone also did not further increase. The caving zones of the upper and lower seams merged into one another when the mining length advanced to $56 \mathrm{~m}$, and the height of the fractured water flow zone continuously increased until its ladder-shaped outline reached the bottom clay layer. The maximum height of the zones reached 25.1 and $68.5 \mathrm{~m}$, respectively, above the upper seam after excavation was completed on the upper and lower seams along the dip direction.

\section{Influence of $h / M$ on failure interactions}

Figure 10 shows a simplified numerical model. The model is constructed in accordance with the cross-section of a prototype along the dip of Panel 3302S to simulate and compare the displacements, stresses and failures after coal recovery from the upper and lower seams. The length and width of the 2D model are 1068 and $167 \mathrm{~m}$, respectively. The overburden is divided into 15 groups according to their geological engineering and geotechnical properties. Figure 11 shows comparisons of the vertical displacements, maximum and minimum principal stresses and tension and plastic zones along the strike directions. Figures on the left column of Fig. 11 are results after recovery of the upper seam of No. 3 and the right column is results for the lower seam of No. 3. Results indicate obvious interaction and superposition of the close-seam mining. For example, a cutting height of 6.0 and $4.3 \mathrm{~m}$ is modeled for the upper and lower seams, respectively, with an interburden thickness of $10.0 \mathrm{~m}$. After excavation of the upper seam, the height of the caving and fractured water flow zones reached 22 and $54 \mathrm{~m}$, respectively, and increased to 28.5 and $65.4 \mathrm{~m}$ in response to excavation of the lower seam. The results also show obvious interactions of close-seam mining on overburden failure and stress distributions.

Table 5 lists the results of the other 18 numerical models to investigate the influence of the ratio of the overburden thickness $(h)$ to the cutting height $(M)$ of the lower seam, i.e., $h / M$, on the interactions of overburden failure. These models have the same cutting height of the upper seam $(5.3 \mathrm{~m})$, varying cutting heights $(2.5,4.3$ and $5.3 \mathrm{~m})$ of the lower seam and varying thicknesses of the interburden (5.0, 7.0, 14.0, 17.0, 19.5 and $22.5 \mathrm{~m}$ ).

Figure 12 shows the interactions of overburden failure influenced by the interburden thickness and the cutting height of the seams. Figure 12a shows the results of NMs No. 1-6 with varying interburden thicknesses between 5.0 and $22.5 \mathrm{~m}$, a cutting height of $5.3 \mathrm{~m}$ for the upper seam, and a cutting height of $2.5 \mathrm{~m}$ for the lower seam. The 


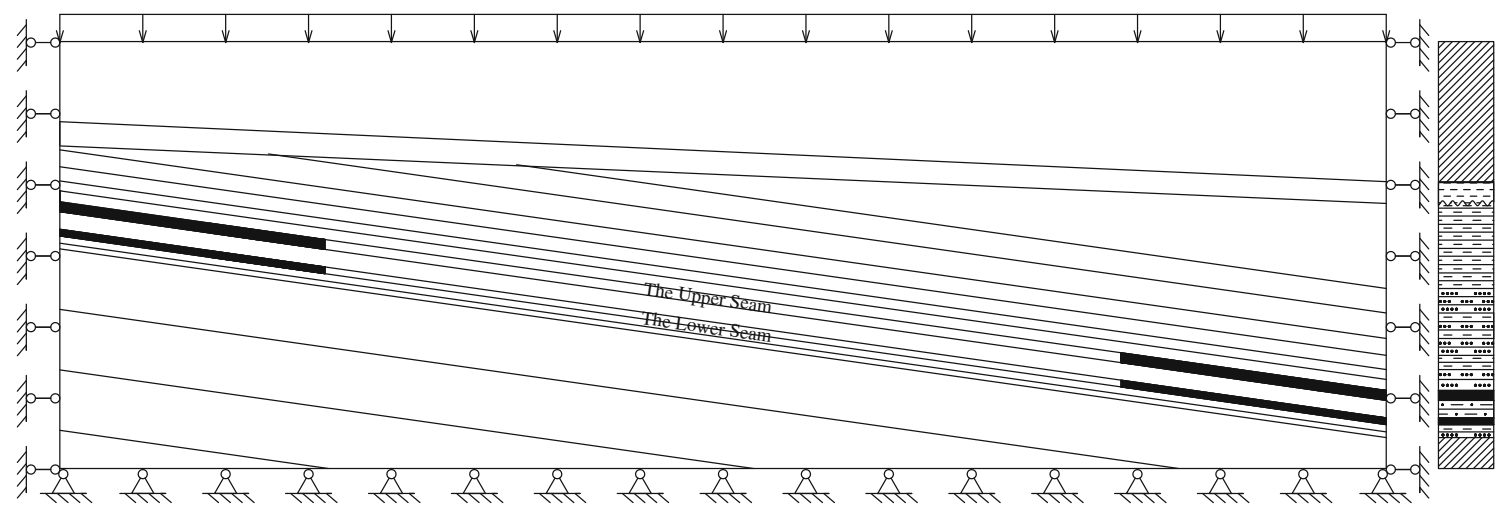

Fig. 10 Schematic numerical model to study the influence of interburden on interactions that result in the superposition of overburden failure

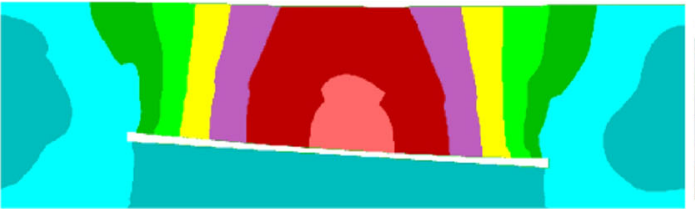

(a)

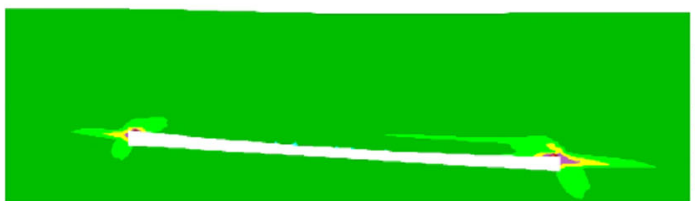

(c)

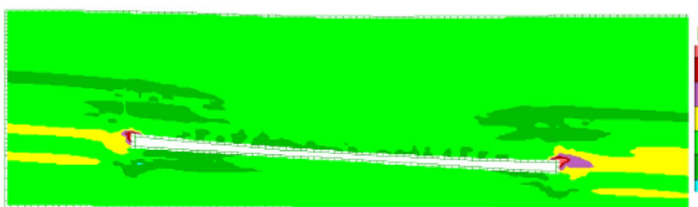

(e)

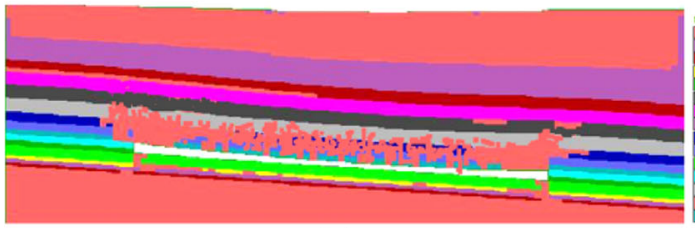

(g)

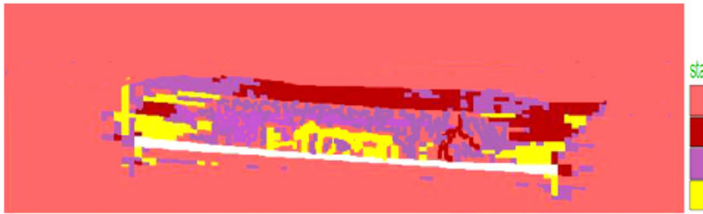

(i)

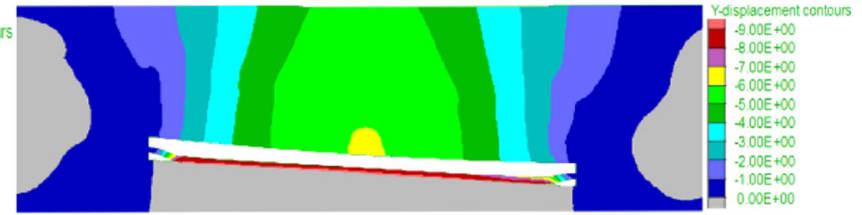

(b)

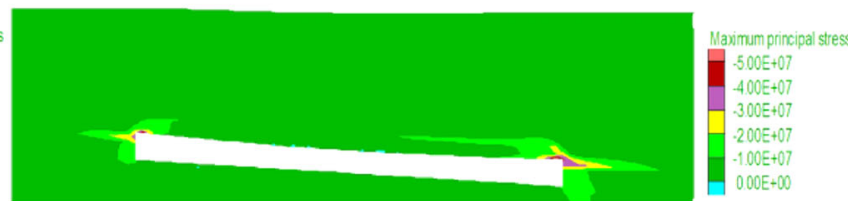

(d)

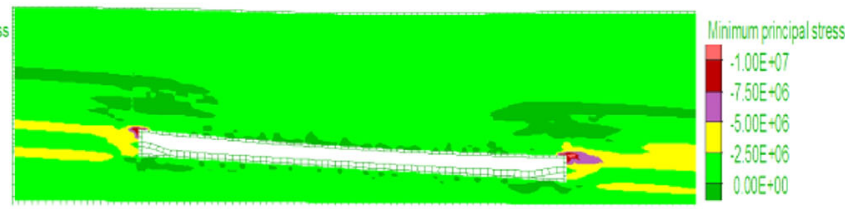

(f)

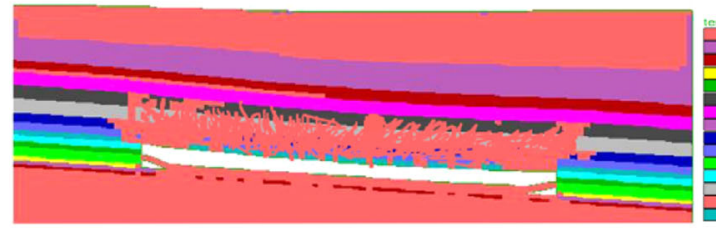

(h)

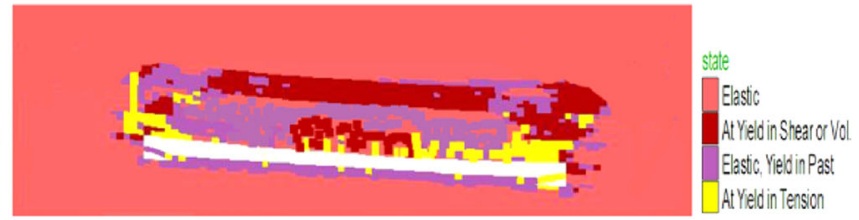

(j)

Fig. 11 Comparison of numerical results after mining the upper and lower seams along the dip. a, b Vertical displacement; c, $\mathbf{d}$ maximum principal stress; e, $\mathbf{f}$ minimum principal stress; $\mathbf{g}$, $\mathbf{h}$ tensile stress; $\mathbf{i}, \mathbf{j}$ plastic zone.

height of the caving zone slightly increased with increases in the ratio $h / M$ until it reached 6.8 with a corresponding interburden thickness of $17.0 \mathrm{~m}$. This means that when $h / M$ is greater than 6.8 , the interactions of the caving zone induced by the recovery of coal in the lower seam and the recovery of the upper seam can be neglected without 
Table 5 Numerical results of overburden failure zone heights for close-distance seam mining

\begin{tabular}{|c|c|c|c|c|c|c|c|c|}
\hline \multirow[t]{2}{*}{$\begin{array}{l}\text { Numerical model } \\
(\mathrm{NM}) \text { no. }\end{array}$} & \multirow[t]{2}{*}{$\begin{array}{l}\text { Cutting height } \\
\text { of upper seam }(\mathrm{m})\end{array}$} & \multirow[t]{2}{*}{$\begin{array}{l}\text { Cutting height } \\
\text { of lower seam } M(\mathrm{~m})\end{array}$} & \multirow[t]{2}{*}{$\begin{array}{l}\text { Thickness of } \\
\text { interburden } h(\mathrm{~m})\end{array}$} & \multirow[t]{2}{*}{$h / M$} & \multicolumn{2}{|c|}{$\begin{array}{l}\text { Mining upper } \\
\text { seam }\end{array}$} & \multicolumn{2}{|l|}{$\begin{array}{l}\text { Mining upper } \\
\text { and lower seams }\end{array}$} \\
\hline & & & & & $H_{\mathrm{c}}(\mathrm{m})$ & $H_{\mathrm{f}}(\mathrm{m})$ & $H_{\mathrm{c}}(\mathrm{m})$ & $H_{\mathrm{f}}(\mathrm{m})$ \\
\hline 1 & 5.3 & 2.5 & 5.0 & 2.0 & 14.36 & 56.20 & 20.86 & 74.28 \\
\hline 2 & & 2.5 & 7.0 & 2.8 & 15.45 & 53.82 & 23.23 & 85.79 \\
\hline 3 & & 2.5 & 14.0 & 5.6 & 16.23 & 54.02 & 24.36 & 88.68 \\
\hline 4 & & 2.5 & 17.0 & 6.8 & 13.73 & 58.10 & $11.4213 .62(\mathrm{~L})$ & 87.71 \\
\hline 5 & & 2.5 & 19.5 & 7.8 & 14.55 & 58.25 & $10.3212 .79(\mathrm{~L})$ & 58.72 \\
\hline 6 & & 2.5 & 22.5 & 9.0 & 8.56 & 43.56 & $8.4112 .33(\mathrm{~L})$ & 45.83 \\
\hline 7 & & 4.3 & 5.0 & 1.2 & 16.62 & 63.21 & 21.32 & 62.89 \\
\hline 8 & & 4.3 & 7.0 & 1.6 & 15.50 & 55.30 & 23.90 & 64.80 \\
\hline 9 & & 4.3 & 14.0 & 3.3 & 15.23 & 54.75 & 27.98 & 63.56 \\
\hline 10 & & 4.3 & 17.0 & 3.9 & 15.12 & 55.25 & 28.81 & 77.46 \\
\hline 11 & & 4.3 & 19.5 & 4.5 & 15.30 & 53.51 & $15.3011 .90(\mathrm{~L})$ & 70.53 \\
\hline 12 & & 4.3 & 22.5 & 5.2 & 10.40 & 45.90 & $14.6113 .27(\mathrm{~L})$ & 52.01 \\
\hline 13 & & 5.3 & 5.0 & 0.9 & 17.11 & 65.13 & 23.87 & 77.80 \\
\hline 14 & & 5.3 & 7.0 & 1.3 & 15.71 & 62.56 & 25.10 & 83.41 \\
\hline 15 & & 5.3 & 14.0 & 2.6 & 16.53 & 66.12 & 29.21 & 86.58 \\
\hline 16 & & 5.3 & 17.0 & 3.2 & 13.89 & 55.92 & 35.06 & 89.72 \\
\hline 17 & & 5.3 & 19.5 & 3.7 & 8.82 & 49.85 & $10.3011 .64(\mathrm{~L})$ & 51.20 \\
\hline 18 & & 5.3 & 22.5 & 4.3 & 9.02 & 41.06 & $11.9512 .14(\mathrm{~L})$ & 41.76 \\
\hline
\end{tabular}

(L) denotes that the height of the caving zone induced by mining the lower seam does not merge with that of the upper seam; therefore, the height is calculated from the roof of the lower seam. The others are all calculated from the roof of the upper seam

$H_{c}$ height of caving zone, $H_{f}$ height of fractured water flow zone

obvious calculation errors. The interactions of the fractured water flow zones induced by mining of the two seams showed the same performance; that is to say, when $h / M$ is greater than 6.8 , the interactions could be neglected and the mining of the lower seam barely increases the height of the fractured water flow zone induced by mining of the upper seam. Therefore, the height of the caving zone can be calculated in terms of single-seam excavation when the $h /$ $M$ ratio is greater than 6.8 in this type of geological and mining condition, while the height of the fractured water flow zone remains almost the same as that induced by upper seam mining. Figure $12 \mathrm{~b}$ shows the results of NMs No. 7-12 for a cutting height of $4.3 \mathrm{~m}$ for the lower seam and the same conditions mentioned above. In this case, the turning point of $h / M$ is 4.5 for the interactions of the caving zone and 3.9 for the fractured water flow zone. Moreover, Fig. 12c shows results for NMs No. 13-18; the $h / M$ of the interactions in mining the upper and lower seams at a cutting height of $5.3 \mathrm{~m}$ is 3.7 and 3.2 for the caving and water flow fracture zones, respectively.

Figure 13a summarizes some of the results of this paper and those from the literature (Zhang 2010; Guo 2011; Xu et al. 2013; Luan et al. 2010) to illustrate the interactions of overburden failure due to recovery of coal from multiple seams, with varying interburden thicknesses and cutting heights of the lower seam. If a point that represents $(M, h /$ $M$ ) falls under Line D, interaction or superposition should be taken into account to calculate the height of the overburden failure (Fig. 13b). Otherwise, the interaction can be neglected when the point drops above Line D; therefore, the height of the caving zone can be calculated by treating it single-seam mining, while the height of the fractured water flow zone will not be surpassed due to mining of the upper seam (Fig. 13c). Line D may be defined as the dividing line that determines whether interaction causes overburden failure superposition in close-seam mining.

The results of this paper could provide a helpful reference in the recovery of coal in close-distance seams by using the LTCC method. However, the interactions presented in this paper still need further investigation. An orthogonal array can be adopted to investigate the influence of factors (overburden and interburden geotechnical properties, cutting heights of multiple seams) on the interactions of multiple-seam mining in further research. Multiple-seam mining with more than two seams of different geological engineering structure, discontinuities, geo-stress environments and dip angles, especially for mining of steeply 

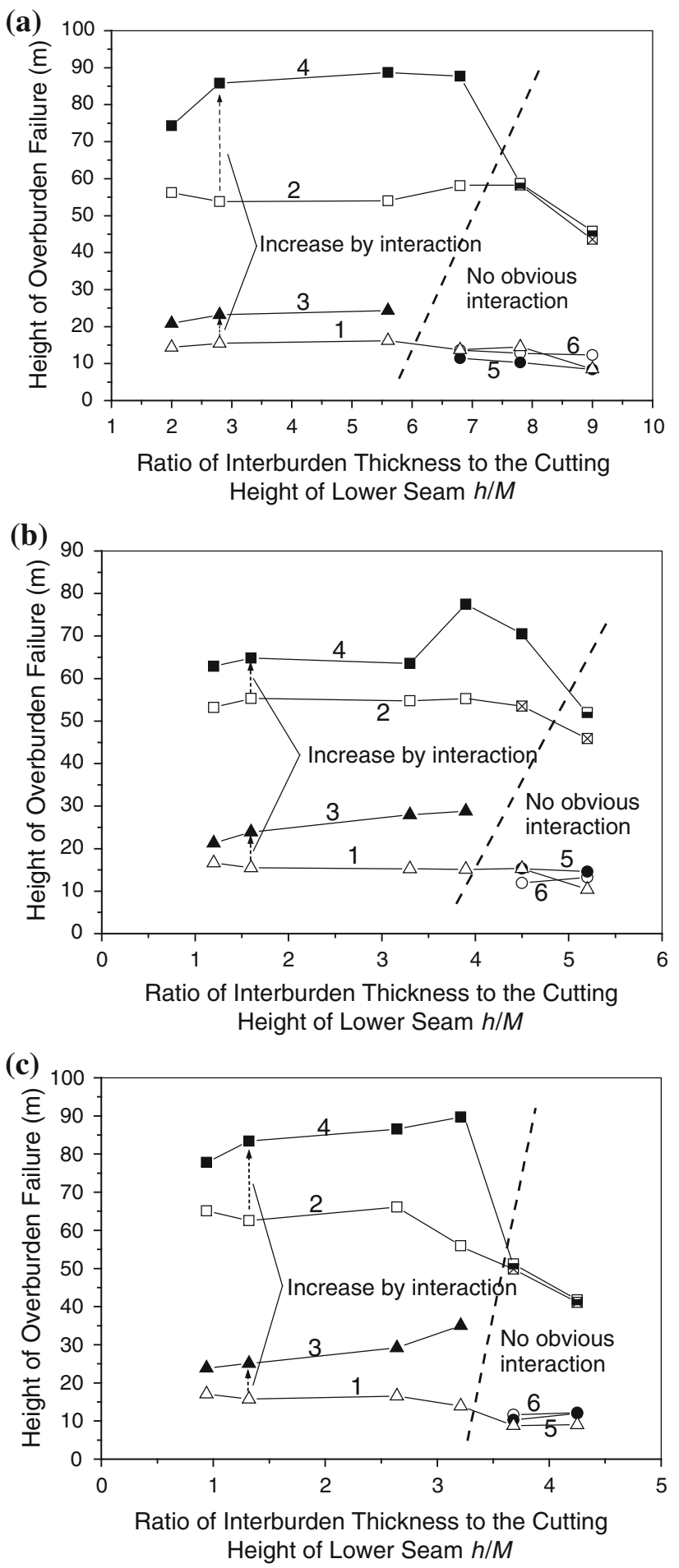

Fig. 12 Height of overburden failure zone due to close distance seam mining. Notes: 1 height of caving zone after excavation of the upper seam; 2 height of water flow fracture zone after excavation of upper seam; 3 height of water flow fracture zone after excavation of upper and lower seams (calculated from the roof of the upper seam); 4 height of water flow fracture zone after excavation of upper seam (calculated from the roof of the upper seam); 5 height of caving zone after excavation of upper and lower seams (calculated from roof of upper seam); 6 height of caving zone after excavation of upper and lower seams (calculated from roof of lower seam)

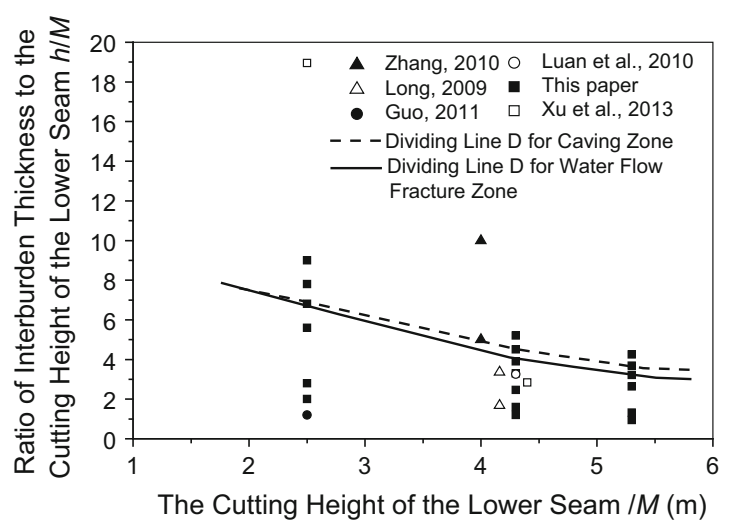

(a)

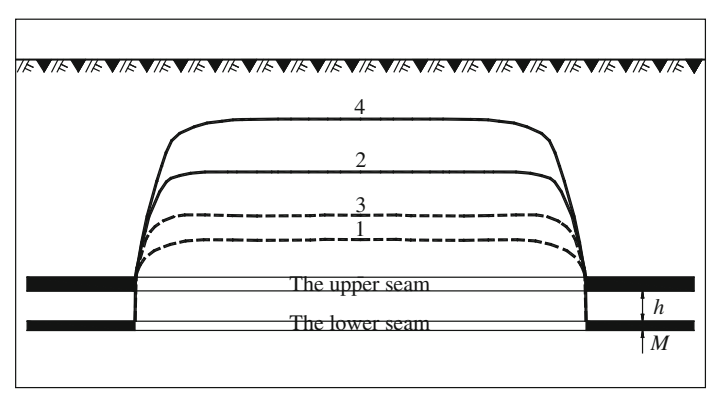

(b)

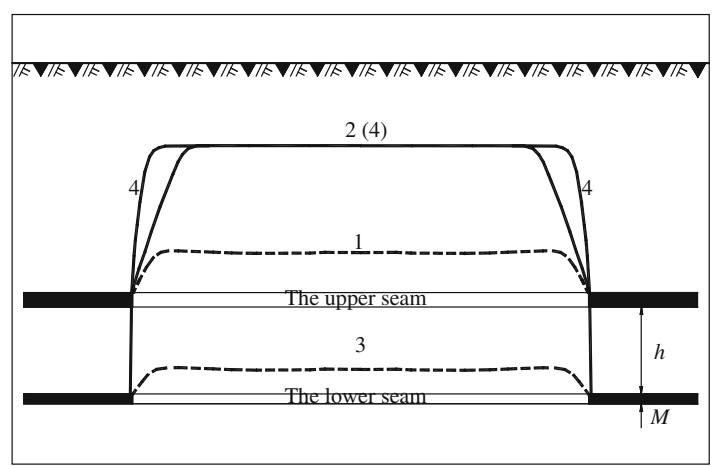

(c)

Fig. 13 Influence of interburden thickness on interactions that lead to the superposition of overburden failure. a Influence of $h / M$ on interactions that lead to superposition of overburden failure. b Below Line D: failure height is increased by interactions when mining the lower seam. c Above Line D: no obvious increase of failure height when mining the lower seam. Note: 1 caving zone induced by mining upper seam; 2 water flow fracture zone induced by mining upper seam; 3 caving zone induced by mining upper and lower seams; 4 water flow fracture zone induced by mining upper and lower seams

dipping seams, will also be further considered. Moreover, coupling the seepage, failure and stress fields should be taken into account for an intrinsic understanding of the mechanism of multiple mining interactions. Results need to be validated by more in situ measurements. 


\section{Conclusions}

Multiple methods, including in situ measurements, scale model testing, numerical simulations and empirical formulas are used in this paper for the investigation of interactions on overburden failure due to mining of multiple thick coal seams using longwall caving. Included is a case study on the Cuizhuang Coalmine that uses LTCC to mine thick seams in the Shandong province of China. The paper focuses on the interactions from the development of the caving zone and fractured water flow zones, which play a significant role in the safety evaluation and technical decision-making when mining under surface water and groundwater. The influence of the interburden thickness, cutting heights of the seams and geotechnical properties of the overburden on the interactions and superposition of overburden failure have been analyzed in detail and the following conclusions are drawn.

1. The results from the in situ measurements, scale modeling and numerical simulations show a good agreement and, therefore, validate the scale and numerical modeling methods by examining the influencing effects on the interactions in the mining of multiple thick coal seams using the longwall caving method.

2. Results of the scale and numerical modeling indicate that the interburden thickness and cutting height have a significant influence on overburden failure in the multiple seam interactions of caving and fractured water flow zones. The interactions decrease with increases in the interburden thickness. The interaction cannot be neglected between two close seams when the ratio of the interburden thickness to the cutting height of the lower seam is less than a defined critical value.

3. A dividing Line $D$ has been determined for the calculation of the interactions on overburden failure and proposed according to the results of this paper and previous studies. Line D conceptually determines whether it is necessary to take the interactions in multiple seam mining into consideration in the calculation of the heights of the caving and fractured water flow zones. When $(M, h / M)$, where $h / M$ represents the ratio of the interburden thickness $h$ to the cutting height of the lower seam $M$, are above Line $\mathrm{D}$, the caving zone induced by mining the lower seam does not propagate to the caving zone induced by mining the upper seam. The height calculations can then be neglected in the interactions of overburden failure without resulting in obvious errors. Otherwise, when $(M, h / M)$ fall below Line $\mathrm{D}$, the interaction and superposition of the overburden failure must be considered in the calculation of the heights of the caving and fractured water flow zones.
Acknowledgments The authors would like to acknowledge financial support from the National Natural Science Foundation of ChinaShenhua Group Jointly Funded Project under Grant No. 51174286, the National Key Basic Research Program under Grant No. 2013CB227903, the Fundamental Research Funds for the Central Universities and a Project Funded by the Priority Academic Program Development of Jiangsu Higher Education Institutions (PAPD). The first author was funded by the China Scholarship Council (CSC) during his visit to Ryerson University, Canada. Prof. Weifeng Yang and $\mathrm{PhD}$ candidate Mr. Wenxue Wang of the China University of Mining and Technology are greatly appreciated for their editorial help in preparing the manuscript. We would also like to acknowledge the reviewers for their invaluable comments.

Open Access This article is distributed under the terms of the Creative Commons Attribution License which permits any use, distribution, and reproduction in any medium, provided the original author(s) and the source are credited.

\section{References}

Alehossein H, Poulsen BA (2010) Stress analysis of longwall top coal caving. Int J Rock Mech Min Sci 47:30-41. doi:10.1016/j. ijrmms.2009.07.004

Chanda ECK (1989) Evaluation of success probability in multiple seam room-and-pillar mining. Min Sci Technol 9:57-73

Chekan GJ, Matetic RJ, Galek JA (1986) Strata interactions in multiple-seam mining-two case studies in Pennsylvania. US Department of Interior, Bureau of Mines, Report of Investigations 9056, Pittsburgh

Chekan GJ, Matetic RJ, Galek JA (1988) Loading characteristics of pillars in multiple-seam mining operations. US Department of Interior, Bureau of Mines, Report of Investigations 9173, Pittsburgh

Chekan GJ, Matetic RJ, Dwyer DL (1989) Effects of abandoned multiple seam workings on a longwall in Virginia. US Department of Interior, Bureau of Mines, Report of Investigations, 9247, Pittsburgh

China State Bureau of Coal Industry (2000) Regulations for coal mining and coal pillar leaving under building, water, railway and main shaft and tunnel. China Coal Industry Press, Beijing (in Chinese)

Gao F, Stead D, Coggan J (2014) Evaluation of coal longwall caving characteristics using an innovative UDEC trigon approach. Comput Geotech 55:448-460. doi:10.1016/j.compgeo.2013.09.020

Guo J (2011) Research on destruction rule of overlying strata with mining in close distance coal seam. Shanxi Coking Coal Sci Technol 9:4-7 (in Chinese)

Heasley KA, Akinkugbe O (2005) Simple program for estimating multiple-seam interactions. Min Eng 57:61-66

Hoek E, Brown ET (1997) Practical estimates of rock mass strength. Int J Rock Mech Min Sci 34:1165-1186. doi:10.1016/S13651609(97)80069-x

Humphries P, Poulsen B (2008) Geological and geotechnical influences on the caveability and drawability of top coal in longwalls. In: Aziz N (ed) Coal 2008: coal operators' conference. University of Wollongong and the Australasian Institute of Mining and Metallurgy, Australia, pp 56-66

Itasca (2009) FLAC3D-Fast lagrangian analysis of continua in 3 dimensions, ver. 4.0. user's manual. Minneapolis

Khanal M, Adhikary D, Balusu R (2011) Evaluation of mine scale longwall top coal caving parameters using continuum analysis. Min Sci Technol (China) 21:787-796. doi:10.1016/j.mstc.2011.06.027 
Luan Y, Li J, Ban X, Sang C, Zhang C, Ma D (2010) Observational research on the height of water flowing fractured zone in repeated mining of short distance coal seams. J Min Saf Eng 27:139-142 (in Chinese)

Mark C (2007) Multiple-seam mining in the United States: background. In: Mark C, Tuchman RJ (eds) Proceedings: new technology for ground control in multiple seam mining. US Department of Health and Human Services, Public Health Service, Centers for Disease Control and Prevention, National Institute for Occupational Safety and Health, Pittsburgh, DHHS (NIOSH) Publication No. 97-122, IC 9495, pp 3-14

Mark C, Chase FE, Pappas DM (2007) Multiple-seam mining in the united states: design based on case histories. In: Mark C, Tuchman RJ (eds) Proceedings: new technology for ground control in multiple seam mining. US Department of Health and Human Services, Public Health Service, Centers for Disease Control and Prevention, National Institute for Occupational Safety and Health, Pittsburgh, DHHS (NIOSH) Publication No. 97-122, IC 9495, pp 15-28

Porathur JL, Karekal S, Palroy P (2013) Web pillar design approach for highwall mining extraction. Int $\mathrm{J}$ Rock Mech Min Sci 64:73-83. doi:10.1016/j.ijrmms.2013.08.029

Swift G (2013) Relationship between joint movement and mining subsidence. Bull Eng Geol Environ. doi:10.1007/s10064-0130539-7
Vakili A, Hebblewhite BK (2010) A new cavability assessment criterion for longwall top coal caving. Int J Rock Mech Min Sci 47:1317-1329. doi:10.1016/j.ijrmms.2010.08.010

Xie H, Chen Z, Wang J (1999) Three-dimensional numerical analysis of deformation and failure during top coal caving. Int J Rock Mech Min Sci 36:651-658. doi:10.1016/S0148-9062(99)00027-3

$\mathrm{Xu}$ Z, Sui W (2013) Statistical prediction of overburden failure due to coal mining under sea area. In: Huang $\mathrm{Y}$ et al (eds) New frontiers in engineering geology and the environment. Springer, Berlin, pp 255-258. doi:10.1007/978-3-642-31671-5_46

Xu Y, Li S, Zhao X, Zhang Q, Wang H (2013) Overburden failure laws in working face of short distance thick coal seams group. J Min Saf Eng 30:506-511

Yang W, Sui W, Xia X (2008) Model test of the overburden deformation and failure law in close distance multi-seam mining. J Coal Sci Eng 14:181-185. doi:10.1007/s12404-008-0037-x

Yasitli NE, Unver B (2005) 3D numerical modeling of longwall mining with top-coal caving. Int J Rock Mech Min Sci 42:219-235. doi:10.1016/j.ijrmms.2004.08.007

Zhang Y (2010) Research on failure height and characteristic of overlying strata in mining coal seams with small interval. Coal min Technol 15:9-11 (in Chinese)

Zhang Y, Zhang L (2010) Experimental study on distribution law of residual fissures in overlying stratum under multiple seam mining. J Eng Geol 18:554-999 (in Chinese) 